\title{
The Biophysical Effects of Neolithic Island Colonization: General Dynamics and Sociocultural Implications
}

\author{
Thomas P. Leppard ${ }^{1}$
}

Published online: 25 October 2017

(C) The Author(s) 2017. This article is an open access publication

\begin{abstract}
Does anthropogenic environmental change constrain long-term sociopolitical outcomes? It is clear that human colonization of islands radically alters their biological and physical systems. Despite considerable contextual variability in local specificities of this alteration, I argue that these processes are to some extent regular, predictable, and have socio-political implications. Reviewing the data for postcolonization ecodynamics, I show that Neolithic colonization of previously insulated habitats drives biotic homogenization. I argue that we should expect such homogenization to promote regular types of change in biophysical systems, types of change that can be described in sum as environmentally convergent. Such convergence should have significant implications for human social organization over the long term, and general dynamics of this sort are relevant in the context of understanding remarkably similar social evolutionary trajectories towards wealth-inequality not only islands, but also more generally.
\end{abstract}

Keywords Ecodynamics $\cdot$ Islands $\cdot$ Neolithic $\cdot$ Convergence

\section{Introduction: Long-Term Social Consequences of Environmental Change?}

Are there ineluctable, long-term sociopolitical consequences of anthropogenic environmental change? To what extent are

Thomas P. Leppard

tp126@cam.ac.uk

1 McDonald Institute for Archaeological Research, University of Cambridge, Downing Street, Cambridge CB2 3ER, UK these consequences constrained by - and emergent frominitial socioecological dynamics? In this paper I address the relationship between radical environmental reorganization and its sociopolitical implications through the lens of human-island ecodynamics. I argue that the anthropogenic introduction of invasive species and the eradication of endemics on islands during the Holocene reduced sum biodiversity in predictable ways that, in theory, should have exercised pronounced homogenizing effects on the function of biophysical systems. Such homogenization should, in turn, have promoted parallel adaptive strategies in discrete human populations.

The arrival of humans on islands throughout the later Quaternary exacerbated extirpation and extinction in endemic biotas already predisposed towards fragility, differentially reducing local and sum global taxonomic diversity. Repeated extinction events wrecked endemic ecologies while intact anthropic ecosystems of domesticates, commensals, and parasites were simultaneously introduced wholesale. In the first section of this paper, I review the evidence for these processes at a global scale, showing that food-producing human populations in particular radically reorganize insular biotas. Moving beyond areaspecific studies of insular ecology, I argue that these twin processes of extinction and introduction should have driven ecosystems separated in time and space towards parallel types of organization, a process of biotic homogenization (McKinney and Lockwood 1999). Because abiotic systems (i.e., soil composition; hydrological dynamics) interface with biota to form biophysical systems, emerging anthropogenic homogeneity in biotic organization also drove homogeneity in insular biophysical organization. I utilize modern and experimentally derived data to explore in detail the likely aspects of this biophysical homogeneity, including the emergence of parallel pedological and hydrological dynamics with ramifications for ecosystem organization and function. I build on the general dynamic theory outlined by 
Whittaker and colleagues (Whittaker et al. 2007, 2008; Borregaard et al. 2016) and suggest that these processes in sum are best described as environmental convergence, notwithstanding the recognition that islands with varied geological histories may have moved towards convergence along discrete pathways.

My main objective, in linking these well-understood but infrequently synthesized types of process, is to emphasize that discrete instances of prehistoric human colonization of islands should nonetheless in theory drive structurally similar environmental dynamics. Biophysical processes of this sort have sociocultural implications, however. In conclusion, I suggest that these general dynamics may have imposed parallel types of constraint on the development of otherwise unrelated island societies, forcing mitigation strategies centered around capital investment that, in turn, promoted exaggerated wealth inequality. The relationship between environmental constraint, returns on capital investment, and the emergence of sociocultural complexity on islands (as exemplary, on reduced spatial scales, of likely larger and longer-term general dynamics) demands substantive future attention.

This argument is not data-driven, nor does it lean heavily on exemplification via detailed case studies (indeed, in many cases, it is not clear that the data required to support an argument of this sort exist). Rather, it is explicitly deductive. My interest here is in suggesting: (a) that a particular recurring confluence of ontogenetic conditions - the collision of certain types of biophysical organization (insularity) with human food-production subsistence and its associated ecodynamics (introduction/extinction) - necessarily and radically constrains resulting socioecological process; and (b) that the existence of this constraint is simultaneously overlooked but yet extremely significant for social scientists seeking to account for apparent parallelism or convergence in long-term social and political trends, especially so in the current context of large-scale environmental change. The aim is not to propose a series of deterministic causations, but to emphasize that, just as human subsistence and behavioral choices narrow the window of possible environmental trajectories, so this narrowing in turn re-imposes restrictions on the panorama of human behavior.

\section{Human Colonization and its Biological Effects}

\section{Extinction and Extirpation}

The expansion of our genus around the planet has been conditioned by environmental organization, but it has also recursively altered this organization both directly and indirectly. Direct predation, translocation and introduction, and domestication have all driven biotic change, but human modification of the planet (from forest clearance to changing the chemical composition of the atmosphere and ocean) has also had impacts on other taxa. This range of processes has promoted both extinction and the establishment of invasive taxa beyond their native ranges, thereby radically altering ecological structure but also, in the longer term, affecting genetic variability and remolding evolutionary landscapes.

The most obvious examples of anthropogenic extinctions come from the recent past and the present. A preponderance of evidence suggests that the planet is experiencing a mass extinction event (i.e., loss of $>75 \%$ of extant species within a restricted timeframe) with the likelihood that this process is primarily anthropogenic (Barnosky et al. 2011; Ceballos et al. 2015). Despite the majority of these extinctions clustering towards the more recent end of the Holocene, the 'long tail' of this process extends back into the deeper Quaternary. I ignore here the controversy surrounding whether the extinction of the Pleistocene continental megafauna was driven by human agency, environmental change, or more complex feedback dynamics (Burney and Flannery 2005; Braje and Erlandson 2013; Cooper et al. 2015; Stuart 2015; Villavicencio et al. 2015; Bartlett et al. 2015). What is less open to debate is the profound effect colonizing humans have had on smaller, previously insulated landmasses.

The physiographic organization of islands - as relatively small, discrete types of habitat surrounded by spatially extensive qualitatively divergent habitat — profoundly influences their biotas. ${ }^{1}$ Island biotas (not just faunas, although floras seem in general to respond differently to invasion (Gilbert and Levine 2013; Downey and Richardson 2016)) are peculiarly exposed to extirpation and extinction risks deriving from biological invasions; far more so than continental equivalents (Loehle and Eschenbach 2012; Szabo et al. 2012; Weigelt et al. 2013). This relates to a number of factors that combine to render insular populations fragile. Most obviously, open ocean impinges on dispersal via filtration effects, reducing gene flow between colonists and source populations and correspondingly driving allopatric speciation. Consequently tending to be rich in endemics, island biotas in total thereby contribute disproportionately to sum global biodiversity, with the result that islands offer more candidate taxa for extinction per unit area than non-insular environments. This threat is exacerbated by the restrictions that insular size imposes on population size (Brose et al. 2004) of a given taxon (endemic or not)-keeping populations low and accordingly more greatly exposed to demographic stochastic perturbations (Lande 1993) - and the effective fragmentation ocean promotes in metapopulations (see Rybicki and Hanski 2013). This, alongside the tendency for insular taxa to be very specialized and, in the absence of complex trophic structures,

\footnotetext{
${ }^{1}$ Clearly, in this sense, Afro-Eurasia is just as insular as Tristan da Cunha; interest lies in scalar difference covering - in this instance - almost five orders of magnitude permitting trophic systems whose difference in complexity (measured, for example, either in species number or total population size) probably exceeds five orders of magnitude. See Brose et al. 2004.
} 
predator-naïve, renders island biotas highly responsive (Fordham and Brook 2010), although clearly and accordingly the degree of insular ecological sensitivity varies along a number of dimensions (including size and remoteness but also geologic antiquity and composition and 'type'-oceanic (high/atoll), continental) that causes island ecodynamics to vary broadly.

It should be emphasized that invading species-whether humans or their co-traveler taxa, such as commensals or domesticates (Chapuis et al. 1994; Nogales et al. 2004; Wanless et al. 2007) - do not simply exert pressure via direct predation, although clearly this is significant. In affecting the demographic robustness of a species by preying on it (deliberate forest clearance can be understood as a process comparable to predation (McWethy et al. 2010)), an invader promotes dynamism in the trophic neighbors of that species, potentially driving ecological release in those it consumes and demographic crashes in those that consume it (O'Dowd et al. 2003). The potential for such dynamics to affect the wider system are clear. Importantly, extinction need not be necessary to cause such ecological cascades so much as substantial population reduction, although the permanent removal of a species from an ecosystem (i.e., taxonomic diversity loss) should have observable consequences (i.e., functional diversity loss) (cf. Baiser and Lockwood 2011). Pressure is also exerted by invasive species on ecological relationships beyond the purely oppositional (i.e., predation and competition), with mutualisms, commensalisms, and parasitisms likely to be subject to disruption following extirpation or extinction events (Traveset and Richardson 2006; Sekercioglu 2011; Boyer and Jetz 2014). In general, the processes leading to extinction and extirpation following invasion are complex (e.g., Hanna and Cardillo 2014), but the result is a uniform, gross trend away from elevated biodiversity.

We should accordingly expect the arrival of humans on islands to be transformative. This is borne out in the data. The effect of human colonization (along with co-traveler taxa) on islands is evident from the Upper Palaeolithic, although there exists a possibility that we glimpse ephemeral traces of comparable processes in deep time, with the extinction of the proboscid Stegodon sondaari on Flores at 0.9 mya (van den Bergh et al. 2009) intriguingly close to the earliest dates for hominin incursion into the Lesser Sundas at 1.02 mya (Brumm et al. 2010). The intentional colonization of island groups by hunter-gatherers belonging to our own species, certainly in the Mediterranean, but also in the Caribbean (Steadman et al. 2005), tracks closely with the disappearance of suites of endemic species, with $88.9 \%$ of mammalian endemics lost in the insular Mediterranean at the PleistoceneHolocene boundary (Alcover et al. 1998). The impacts of hunter-gatherers in Near Oceania are harder to gauge. Steadman et al. (1999) suggest anthropogenic avifaunal loss in the Solomons and extinction and range-contraction of the varanids (giant monitor lizards) might be associated with human activity (Hocknull et al. 2009). In general, the patchy data hint at a role for humans in the eradication of several taxa including Stegodon and the elephantid Palaeloxodon, a role which - not least because of sea level rise driving processes of range fragmentation in Sunda and Sahul — is hard to disentangle from broader environmental processes (Louys et al. 2007). The same is true of the Californian Channel Islands; extinctions at colonization seem to have been limited to the duck Chendytes lawi, but there is evidence for extensive resource depletion and concomitant ecosystem effects (Rick et al. 2012; Braje et al. 2017b).

A more reliable signature corresponds with the spread of agricultural, agropastoral, or horticultural (i.e., foodproducing; 'Neolithic' hereafter) ${ }^{2}$ lifeways (see Braje et al. 2017a). In the Caribbean and Mediterranean, with their previous exposure to hunter-gatherers, extinctions continued to occur during the establishment and expansion of agropastoral lifeways (e.g., Steadman and Franklin 2015; Bover et al. 2016). Remote Oceania, which in contrast had not experienced human presence until the arrival of food-producing communities and was by virtue of its geographic organization rich in endemic taxa, underwent radical change at and beyond human colonization horizons, with endemic avifauna and flora in particular witnessing catastrophic losses (Steadman and Martin 2003; Boyer 2010). These losses are almost certainly in part attributable to large-scale environmental change induced, not only by humans behaviors, but also by ecological release in commensal species, in this case the Polynesian Rat Rattus exulans (Hunt 2007; Athens 2009). The Pacific example is striking, not least in the extent to which exaggerated environmental disruption witnessed between 3000 and 500 BP in Remote Oceania prefigures the final cataclysmic arrival of European colonists, their livestock, and their diseases after 500 BP (a topic which I do not consider in detail here). This should not obscure, however, that the rapid traumatization of the endemic Pacific echoed more drawn-out but equally dramatic Holocene eradications in the Mediterranean and the Caribbean.

\section{Translocation and Invasion}

The arrival of humans and their co-traveler species in habitats previously insulated from them drives radical and highly

\footnotetext{
2 'Neolithic' affords such semantic latitude that, depending on how it is defined, it becomes more or less inappropriate contextually. What is necessary, however, is a term which embraces hugely variant situations in which, nonetheless, human communities derived the majority of their terrestrial calories from biota which had gone through, or were going through, processes of domestication. Clearly, the extent to which populations were reliant on terrestrial domesticated biota varied substantially from instance to instance, but nonetheless represents, in all cases, a qualitative break with previous subsistence strategies. Consequently, 'Neolithic' is preferred as the least-worse option.
} 
variable ecological change, but the outcome is almost always the same: pronounced biodiversity loss. Such loss is not only an outcome of processes of attrition, however, but also of processes of translocation and invasion. It should be stressed that ecologists distinguish between newly-arrived species according to their long-term reproductive success and degree of associated ecological impact, in terms of translocated (taxa that reach a new habitat), introduced (taxa that reach a new habitat yet have minimal impact), and invasive (taxa that reach a new habitat and have large-scale impact). Many of the taxa discussed subsequently are commonly viewed as invasive (e.g., Rattus exulans), yet it is worth emphasizing that it may be the case that many introduced taxa-whose impact is not readily observable at the scales or timeframes at which ecological analysis of invasion tends to be undertaken (e.g., Thiara spp.)- may contribute to biodiversity reduction and homogenizing processes. During incipient domestication events around the planet, such species have been bundled together in recurring packages which, in effect, represent artificial ecosystems comprising finite sets of repeated ecosystemic interactions (Çilingiroĝlu 2005). During island colonization, these bundles have often been transplanted wholesale (Kirch 1984), preserving in part extant ecosystemic links between groups of species that co-evolved under the peculiar but aggressively selective conditions of domestication (Boivin et al. 2016).

In the Mediterranean, and subsequently much of the planet after 500 BP, translocations included the classic Southwest Asian Neolithic package of cereals and pulses including barley (Hordeum spp.) and wheat (Triticum spp.) (Willcox 2013; Arranz-Otaeguia et al. 2016) alongside domesticated ungulates (most notably cow, Bos taurus; pig, Sus scrofa domesticus; sheep, Ovis aries; and goat, Capra hircus) (Zeder 2008). In the Pacific (and across the Indian Ocean, to Madagascar and the Comoros (Crowther et al. 2016)), major translocations include coconut (Cocos nucifera), taro (Colocasia esculenta), yam (Dioscorea spp.), banana (Musa spp.), and breadfruit (Artocarpus altilis), alongside pig, dog, and the domesticated chicken, Gallus gallus domesticus. It should be noted that in the Pacific there exists considerable variability among islands regarding the precise composition of domesticated, introduced biotas (for example, all three domesticated fauna rarely co-occur). Moreover, the precise sources of these species and the specific dynamics of their domestication are considerably more contentious than in the Mediterranean, but in general a Southeast Asian and Island Southeast Asian origin is a common theme (e.g., Denham 2011; Gunn et al. 2011; Barker and Richards 2013; Pitt et al. 2016), with pigs perhaps deriving from domesticated stock in mainland China, but with potential parallel domestication events elsewhere in Southeast Asia (Larson et al. 2010; Bellwood 2011). The Caribbean example diverges slightly because of the absence of domesticated ungulates or cereals (excepting of course maize, Zea mays) from the Americas. Continental faunas were translocated, however, possibly to provide naturally corralled stocks of non-domesticated protein; instances include armadillo (Dasypus sp.), agouti (Dasyprocta sp.), guinea pig (Cavia sp.), peccary (Tayassu/ Pecari sp.), and opossum (Didelphis sp.) (Giovas et al. 2011, 2016; also Stahl 2009). The extent of deliberate translocations of plant foods is not immediately clear. Sporadic evidence for other early Antillean translocations includes Manilkara spp., as Fitzpatrick (2015) notes in providing a comprehensive overview of flora exploited for nutritional purposes during the Ceramic Age (traditionally understood to have involved much more intensive and deliberate management of domesticates and quasi-domesticates than the preceding Archaic), including common bean (Phaseolus vulgaris), sweet potato, (Ipomoea batatas), and marunguey (Zamia spp.), although it is not clear whether the Antilles were included in the native ranges of these taxa. Maize itself - certainly a translocationis evidenced in human dental calculus from the island Caribbean from around 2000 BP (Mickleburgh and PaganJimenez 2012). Data from Trinidad may push this introduction back to the Mid Holocene (Pagán-Jiménez et al. 2015), although the insular status of the island during Mid Holocene seastands is unclear and, even if Trinidad was insular during the Mid Holocene, the over-water distance to the South American mainland would have been negligible.

Various other taxa have been translocated accidentally, such as the house mouse Mus musculus domesticus, as well as various species of shrew, during Mediterranean Neolithicization (Vigne 1988; Cucchi et al. 2005), and the aforementioned Polynesian Rat, Rattus exulans, during the colonization of Polynesia (although there is debate regarding whether this was indeed an accidental or deliberate translocation (Matisoo-Smith et al. 1998; Allen 2015)). Similarly, murids of several types were unintentionally translocated in the Indian Ocean (Fuller et al. 2011). The process was not limited to vertebrates; other instances include the translocation of the aquatic snail Thiara spp. and other molluscs to Remote Oceania, potentially in the context of wetland taro cultivation (Kirch 1996; Kirch et al. 2009). There are also other, less archaeologically conspicuous examples. Movement of exotic pathogens has attracted most attention within the context of European expansion and colonialism after 500 BP (e.g., Nunn and Qian 2010), but colonizing Neolithic humans inevitably translocated novel pathogenic bacteria and viruses (as well as relatively benign unicellular organisms; e.g., gastrointestinal microbiota) to previously insulated environments, provoking new, if now unrecoverable, ecological relationships.

In the Mediterranean, the Caribbean, and the Pacific, Neolithic colonization - essentially comprising a series of repeated biological invasions - drove substantial change in biotic organization. These processes were to an extent regionally specific (as regards the ecological coherence of discrete types 
of Neolithic package) but, in terms of general process, are comparable; I return to this distinction shortly. These initial Neolithic island colonizations were followed by both intentional and accidental translocations, as well as extinctions (Ratcliffe and Calaby 1958; Helmus et al. 2014), on a prodigious scale, associated with the European expansion over the last half millennium. This second phase of introductions has clearly exacerbated and more comprehensively generalized these biotic changes. The time depth of these processes beyond the Late Holocene (and concomitant implications for human social development) is, however, less frequently emphasized, and accordingly I focus on initial Neolithic colonization. Specifically, I suggest that drastic, short-term reduction in sum biodiversity on islands is essentially a process of homogenization. This homogenization is likely to have had effects and these effects in turn should have severely constrained the landscape of human subsistence choices in the medium to long-term.

\section{Neolithic Colonization as a Driver of Biotic Homogenization}

The effect of island colonization by humans over the recent Quaternary has not simply been loss of biodiversity and destruction of endemic ecosystems, but replacement of these ecosystems with highly anthropogenic portmanteau ecologies. Evidently, at local scales each ecological situation is contextually unique, and we should expect different types of insular geologic and biogeographic environments to exhibit varied responsiveness, but the repeated introduction of species with finite behavioral repertoires encouraged similar types of ecosystemic relationships; for example, impressively varied late Pleistocene ungulate herbivory on insular Mediterranean maquis flora, involving a range of higher taxa, was replaced during the Holocene largely by two species of Caprini. This is a process of biotic homogenization.

Biotic homogenization occurs when human activity affects the organization of biota in a non-random fashion, negatively affecting a larger number of taxa and positively affecting a smaller number. The outcome, as large numbers of taxa undergo extinction and smaller numbers of taxa experience range expansion, is reduced spatial biodiversity (McKinney and Lockwood 1999; Olden 2006). Taxonomic variety should not be simply equated with behavioral diversity; ecological roles performed by a given endemic species may, following its eradication, have been closely approximated by an invasive species, and we cannot assume that loss of ecosystem function necessarily accompanies species loss (i.e., we must differentiate taxonomic and functional homogenization (Olden et al. 2004; Baiser and Lockwood 2011)). In general, however, we can expect repeated eradication of endemics and introductions of very limited biotic suites to suppress behavioral diversity in a manner comparable to, if not matching in extent, loss of genetic diversity, driving the emergence of dominant, repeated sets of ecological interactions.

Different types of environment are likely to witness different rates and types of homogenization process. There is reason to suppose that the same factors that make island biota relatively responsive may also combine to make them more susceptible to homogenization processes (Cassey et al. 2007). This perhaps in part relates to the possibility that homogenization is greater at low species richness (Olden and Poff 2003), a condition characteristic of insular environments, and that it depresses those factors that encourage allopatric speciation (Olden et al. 2004). While the general trend is towards insular biotic homogenization (Rosenblad and Sax 2016), it does appear that fauna and flora gravitate towards homogeneity at differing rates (Shaw et al. 2010; but Kueffer et al. 2010), although scales of temporal analysis adopted affect assessment of overall process (Rosenblad and Sax 2016). The key recognition, based on the foregoing review of extinctions and translocations, is that we can establish homogenization as an active ecological process with a substantial time depth, potentially up to and beyond the Pleistocene-Holocene boundary (although more recent in, e.g., Remote Oceania).

I suggested above that these processes of homogenization were regionally specific regarding the ecological coherence of Neolithic packages but, in terms of general process, were comparable. Unlike current homogenizing processes, individual island theaters associated with discrete Neolithic packages experienced greater intra-regional than inter-regional convergence prior to $500 \mathrm{BP}$; related invasive dynamics on, for example, Mid Holocene Cyprus and Crete drove greater homogeneity between them than between Cyprus and Late Holocene Puerto Rico. This is not substantially problematic, however, as - from the perspective of the wider implications of processes, rather than within a context of conservation biology - it is the outcomes of such processes, rather than the degree of sum global homogeneity, that is most relevant.

This review of data for extinction and translocation indicate that biotic homogenization has been an active ecological process on islands over the later Quaternary. I now explore the possibility that biotic homogenization promoted similar processes beyond the biosphere. In particular, that homogenizing biotas, interfacing with abiotic systems, should have driven regular and repeated biophysical changes that resulted in processes of insular environmental convergence.

\section{Biophysical Outcomes of Insular Biotic Homogenization}

Biota interface with abiotic physical systems. Various organic including growth, metabolism, mobility, and decay involve the structural reorganization of the abiotic environment around the organism. Accordingly, it is appropriate to describe 
those aspects of environmental systems in which biotic and abiotic processes are especially intertwined (most notably pedology and hydrology) as biophysical systems. Biotic homogenization has implications for insular biophysical systems.

\section{Soil Biogeochemistry and Integrity}

Soils interface with organisms in a variety of qualitatively discrete yet related ways, and are central to ecosystem organization and function (Vereecken et al. 2016). Most obviously, microbiota in soils form parts of larger ecosystems, but more strictly biophysical relationships include the manner in which biota affect the biogeochemical composition of soils, as well as their mechanical and structural properties. An important resulting recognition is that structural cohesion of soils is not independent of biogeochemical and taxonomic diversity in soil and associated plant communities, and that the types of biotic homogenizing processes evident on islands during Holocene colonization have, in other contexts, driven predictable processes as regards soil content and integrity.

The composition of plant communities is a primary determinant of soil biogeochemistry, as flora and soils exist in dynamic biochemical feedback relationships (plant-soil feedbacks (PSFs), Ehrenfeld et al. 2005). Accordingly, changes in the composition of plant communities during the transition from more heterogeneous to more homogeneous biota have implications for pedological dynamics. Community composition, as noted, can be affected along a variety of dimensions; invasive plants can outcompete and replace endemics, and behavior in faunas - most obviously herbivory, but also including mobility and associated disturbance, excretion, composition of gastrointestinal microbiotas, etc.- - homogenizing along similar gradients can drive parallel types of change in soil nutrient organization (e.g., SánchezPiñero and Polis 2000). We can deal first with plant-plant interactions. Plant-soil feedbacks are interrupted or modified during biological invasions (Wolfe and Klironomos 2005; Stinson et al. 2006), although the manner in which these disruptions occur is not fully understood (Suding et al. 2013; Schittko et al. 2016). What is clear is the capacity of invasive species to interrupt plantsoil feedbacks to their own comparative advantage and to the disadvantage of native species (Callaway et al. 2004; Perkins et al. 2016), constructing preferentially less biogeochemically diverse soils. In addition to community turnover in strictly floral terms, herbivory on the part of invasive and comparatively Homogeneous faunas (especially but not only domesticated ungulates) may adversely affect native plants more severely than invasive species in a series of manners, either biased against them because of their relative ecological naïveté or, where there is no clear herbivorous preference for endemics versus exotics, nonetheless having greater effect on endemic species via smaller population sizes and resulting greater exposure to demographic stochasticity. The sum effect of biotic homogenization, via these varied impact pathways, is radical reorganization away from diversity in soil biogeochemistry.

The effects of homogenization in soil biogeochemistry are substantial; not only in terms of of the constraints that homogeneous soils subsequently impose on ecosystem development as regards biomass potential and nutrient availability (in the context of different plant taxa possessing different requirements (Marschner and Marschner 2012)), but also in terms of pedological structural properties. Soil chemistry has implications for the robustness of pedological units insofar as it determines the spatial distribution of community members and thereby root structure, which directly promotes soil integrity (Bergmann et al. 2016). In the context of PSF dynamics in which increasing homogeneity in soil biogeochemistry promotes biodiversity-loss in communities (Perkins et al. 2016), experimental work that suggests that decreased floral biodiversity correlates positively with inability of soils to resist erosion is consequently significant (Berendse et al. 2015); more so if exacerbated soil loss and decreased biodiversity exist in a feedback relationship (cf. Garcia-Fayos and Bochet 2009; Bergmann et al. 2016). Bautista et al. (2007) find that higher functional diversity corresponds with lower runoff because of the relationship between higher diversity and patch density. These studies indicate that biogeochemical homogenization of soils drives community dynamics that in combination negatively affect soil stability and retention.

It is not only shifts in biogeochemical organization associated with root depletion that promote macro-scale change in soils, and here we can briefly consider ungulate herbivory and its pedological effects in terms of direct mechanical impacts. Comparative data from the relatively recent introduction of the domestic goat Capra hircus to the Pacific and South Atlantic suggest that substantial biophysical change might be anticipated during comparable introductions in the Early-Mid Holocene insular Mediterranean. Goat herbivory is implicated in erosion of topsoils (Mwendera et al. 1997; Yong-Zhong et al. 2005; Yocom (1967) reports $1.9 \mathrm{~m}$ of soil lost from the Haleakalā Crater on Maui since introduction). This derives from their eradication of native (as well as invasive) flora and consequent sub-surface biomass loss (Cronk 1989; Chynoweth et al. 2013), capacity to create ecological conditions that favor invading taxa (Wilcove et al. 1998), and the associated breakdown of nutrient-cycling (Hata et al. 2014), processes that are intrinsically interlinked. While the capacity of Capra to drive parallel types of biophysical reorganization in invasions is substantial, the domestic pig Sus scrofa domesticus was introduced prehistorically not only to the insular Mediterranean but also the Pacific, driving similarly large-scale and parallel biophysical change. The omnivory of pigs can promote predictable ecological dynamics at broad spatial scales. Hawai'ian studies indicate that the most conspicuous effects of pig behavior are reduced growth and survival in plant prey-species (Cole et al. 2012; Murphy et al. 2014; see also Campbell and Rudge 1984), which has profound implications 
for soil structure. On O'ahu, areas with pigs present versus areas with pigs excluded experienced much more substantial runoff, associated with the effects of pig-rooting (Dunkell et al. 2011). Nogueira-Filho et al. (2009) note that effects associated with the presence of pigs also include facilitation of dispersal of exotic flora and soil degradation via trampling and mobility. Overall, in contexts where biotic homogenization includes as a main component the introduction of stocks of domesticated mammals, there is an evident cross-cultural regularity in resulting pedological processes.

Other taxa beyond introduced ungulates drive homogenizing processes in the biogeochemistry and structural dynamics of island soils. Studies of the emergent environmental properties of commensal invasions focus to some extent on humanmediated introductions to very biogeographically isolated islands after 500 BP, but we can in part retroject these ecodynamic trajectories onto Early-Mid Holocene colonization events. Impacts of commensals, especially murids, have attracted most attention (Angel et al. 2009; Bolton et al. 2014; Simberloff 2009), not least in their capacity to adversely affect nutrient input (especially of phosphorous and potassium) via predation on seabirds, which otherwise act as biogeochemical vectors between marine and terrestrial ecosystems (Mulder et al. 2011), although other modes of predation also drive down taxonomic biodiversity. The general trend is again one of impoverishment, with human commensal species contributing to processes of biogeochemical soil depletion - and consequently sum homogenization - alongside deliberately introduced fauna.

What are the main implications of insular biotic homogenization for pedological structure? Biotic homogenization is equivalent to loss of variability, and this is mirrored in biophysical systems. A direct consequence of the agropastoral colonization of islands should be increasingly parallel dynamic soil processes: loss of heterogeneity in the type of PSFs encouraging expansion of exotics at the expense of native taxa, with resulting impoverished and uniform patterns of nutrient distribution reducing below-surface biomass and degrading pedological integrity. This in turn promotes predictable changes in soil dynamics at large spatial scales, as the hydrological system interacts with soils. Root biomass is a primary inhibitor of rill erosion (Gyssels et al. 2005); decreasing root biomass diminishes the efficacy of vegetation as a break on the evolutionary transition from splash/sheet erosion to rill/ gully erosion (Woodward 1999; Di Stefano et al. 2013) (a function also of slope gradient and rainfall dynamics), with the latter two types accounting for $>90 \%$ of actual sediment transport (Fang et al. 2014).

\section{Erosion, Hydrology, Sedimentation}

The movement of large amounts of sediment around the landscape by water has ramifications along a number of axes. It substantially reconfigures the distribution of soil biogeochemical components (whether derived from biotic processes or from weathering of geological substrate), in gross terms moving them downslope and towards - and sometimes beyondthe coastline (Pimentel and Kounang 1998; Pimentel 2006). This redistribution involves both the deposition of the material elsewhere, and sum material loss (Ritchie et al. 2007). For example, studies of available soil organic carbon (SOC) have found that SOC eroding from upland soils is differentially retained in downslope soil formations (Nadeu et al. 2014; cf. Kirkels et al. 2014), while some carbon is lost through fluvial transport to, ultimately, the sea. Similar dynamics apply to nutrients, in particular nitrogen and phosphorous; complex interactions between these various components notwithstanding, disruption of nutrient-cycling and general degradation of soil quality is evident generally, especially at parent soils (Quinton et al. 2010). We are essentially dealing with two types of degradation: absolute nutrient loss from the environment, and spatially specific reorganization of the nutrient landscape. The major outcome of this is overall impoverishment of the pedological environment, but a secondary outcome is preferential distribution to areas of deposition and deleterious effects in eroding areas. As nutrient distribution is an important determinant of autotroph biomass (Marschner and Marschner 2012), sediment transport forecloses on the sustainability of thresholds of growth in some areas and provides a new basis for growth in others. It should be emphasized that there is a temporal lag in processes of redistribution that is important at timescales relevant for biota and ecosystem function; soil destruction and movement (i.e., transition to sediment) can be rapid, but pedogenic processes after sediment deposition are much less rapid (Vereecken et al. 2016). The recursive consequences of soil dynamism for ecosystem organization are substantial.

Sediment movement via water transport changes landscape morphology (notably slope), which recursively alters hydrological dynamics, driving up flow-rates in areas of higher relief and retarding waterflow across plains as sediment is deposited. Hydrological organization is a dynamic system, with this dynamism constrained non-randomly by various factors including slope and sediment input and transport (Perron et al. 2012; Willett et al. 2014). Accordingly, increased sediment input into river systems via increased erosion alters the extent to which this input exercises constraint on hydrological dynamics. This has biological implications, as well as those for the physiographic organization of landscapes; increasing volumes of water-borne sediment have impacts on riverine and lacustrine ecosystems, affecting trophic webs and reproduction (Wood and Armitage 1997). Beyond terrestrial hydrological systems, studies suggest that terrigenous sediments can radically disrupt near-shore (and especially lagoonal) environments (Fabricius 2005). We cannot directly correlate modern with prehistoric sedimentation as the chemical burden of 
modern suspended sediments is likely to be more diverse and more deleterious than in Early-Mid Holocene near-shore deposition. Nonetheless, evidence that modern sedimentation can reconfigure coral reef ecosystems via a series of impact pathways beyond those related to toxin accumulation is significant; suspended particles drive changes as diverse as inhibiting photosynthesis by obstructing photic penetration of the water-column (Storlazzi et al. 2015) to altering feeding behavior in fish, as well as entering the trophic system via ingestion (Tebbett et al. 2017). Sedimentation associated with interior island erosion following episodes of prehistoric colonization should be expected to have influenced marine ecosystems along similar pathways, with this influence not only limited to tropical latitudes (e.g., Airoldi and Cinelli 1997).

Downslope sediment transport denudes uplands, exposing geology that had been previously covered by regolith. Weathering of such geology is considered to be central to several biophysical processes, not least the carbon cycle (e.g., Maher and Chamberlain 2014), leading to the introduction of new chemicals to the zone in which the lithosphere and atmosphere interact (Anderson 2012). The potential clearly exists for nutrient losses associated with erosion to be replenished by fresh weathering, although (a) with altered structural conditions in the regolith the release and distribution of such nutrients is likely to be very variable, and (b) heterogeneity in the underlying geology may mean that types and proportions of nutrients released do not conform to previous nutrient ratios. Plant-soil feedbacks suggest that any establishing plant community will, other factors being equal, accordingly diverge from the structural composition of the preceding community.

Clearly, having stressed the degree to which biotic and physical systems intermesh in a series of feedback relationships, it would be possible to continue to track the subsequent implications of these (and other) biophysical outcomes of biotic homogenization, but to do so would be to labor the point. It is evident that various types of ecological processes can cause cascade effects that move through biophysical systems. These effects, in reorganizing physiographic structure, then re-frame the physical conditions which constrain biota, and in this sense this relationship is recursive, and likely to obtain in different instances of island colonization.

\section{The General Dynamics of Neolithic Island Colonization}

\section{Environmental Convergence}

Data clearly suggest that agropastoral colonization of previously insulated habitats during the later Quaternary initiated (via a dual mechanism of extinction and translocation) a series of homogenizing biotic processes. Accordingly, these anthropogenic insular biotas came to more closely resemble one another in terms of relative lack of taxonomic and functional diversity. As biota interface with abiotic systems, so increasingly homogeneous biotas in increasingly homogeneous ecosystems interfaced with biophysical systems. Modern and experimentally derived data on biophysical dynamics suggest that this process would have driven repeated types of dynamics across a range of scales, from the very small (soil biogeochemistry) to the very large (alluvial formation), admitting that the rate and severity of these dynamics should vary significantly depending on local ontogenetic conditions.

This suggests that the central dynamics of postcolonization insular environmental change should be predictable (Whittaker et al. 2007, 2008; Borregaard et al. 2016). Whittaker et al.'s 'general dynamic theory of oceanic island biogeography' (Whittaker et al. 2007; Whittaker et al. 2008) adds a further dimension to the original assumptions of MacArthur and Wilson (1967), emphasizing that the physiographic organization of small volcanic oceanic islands changes over evolutionary time in ways that are generally knowable (Borregaard et al. 2016). In the case of volcanic islands, the taxonomic diversity of each can be contextualized within its position on the temporal spectrum from initial formation through the cessation of volcanic mass-building to erosion and ultimately atoll formation. The evolutionary specifics of the model are not here of immediate interest; more relevant is the notion that initial ontogenetic conditions, interacting with biota, constrain resulting biophysical processes within certain parameters. This concept can be utilized to consider interactions between human colonists and insulated environments in terms of a general dynamic theory. Despite evident diversity in the cultural component of such colonizations, the ecodynamic outcomes are largely similar: Neolithic colonization and its predictable biotic effects impose constraints on biophysical systems such that their organization on islands comes to more closely approximate other such systems. The general outline - parallel types of contextual constraint driving unrelated morphologies towards a common form - suggests that we may best consider this a process of environmental convergence.

I use convergence here in a loose sense to describe a process in which two entities come to resemble one another in their present present morphologies yet whose resemblance masks deep initial morphological variation. In evolutionary biology, convergence is increasingly seen as having a genetic basis; even at macro scales, it is understood to be an outcome of explicitly Darwinian processes. (Losos 2011; McGhee 2011; Stern 2013). Demonstrably, inorganic systems are not under Darwinian selective pressure. Natural selection itself, however, is one of many structured sorting processes, and this provides a useful insight into considering the nature of insular biophysical convergence. With very different pre-colonization biophysical conditions, the suite of effects associated with 
colonization by agropastoral humans exercised comparable types of ecodynamic pressure on islands. Because of the structural parallels in how island biophysical systems are organized, these comparable types of pressure drove comparable emergent outcomes: specifically, biotic homogenization followed by abiotic dynamics associated with homogenization and biodiversity loss. These cascades were recursive, with the biophysical outcomes of biodiversity loss driving greater biotic homogenization. Accordingly, the structural organization of island environments separated in time and space converged to more closely approximate one another.

The goal of this paper has been to emphasize that prehistoric human colonization of islands ineluctably forces biophysical changes along limited and consequently quasipredictable axes. Recognizing that the human capacity to alter biophysical systems such that environmental convergence is the outcome has broader implications, not least for the scholarship regarding the nature and time-depth of the Anthropocene (e.g., Braje and Erlandson 2013). However, I now briefly consider how anthropogenic environmental convergence may have iteratively affected social and political organization of island communities in the aftermath of colonization.

\section{Sociopolitical Implications: Mitigation, Capital Investment, and Wealth Inequality}

From the perspective of human landscape management, the general dynamic landscape processes sketched above are mostly deleterious, in particular soil and nutrient redistribution, but also degradation of marine environments and unpredictability in hydrological organization. Clearly, deleterious processes of this sort (whether anthropogenic or not) have occurred across the planet, but the foregoing discussion suggests we might expect them to be more rapidly or acutely experienced on islands. It is a reasonable assumption that Neolithic societies cross-culturally and characteristically act to mitigate processes viewed as deleterious, in general acting to boost resilience and minimize risk in the short-medium term (e.g., Quintus et al. 2016). I now address how these general environmental dynamics may have prompted strategic responses from Neolithic communities.

Strategies to mitigate such processes would cluster around attempts to limit pedological loss (and boost productivity) via capital investment; programs might take the form of terracing, hydrological management, and nutrient replacement. Diversification within horticultural/agropastoral regimes should also serve to offset calorific losses associated with upslope soil depletion. Recognizing the relatively high productivity of coastal environments in mid- and low-latitude contexts (especially within the latitudinally-determined coral belt), diversification into and increasingly intensive exploitation of offshore resources might also be expected. There is some supporting evidence for this, notably for terracing (e.g., Bevan and Conolly 2011; Quintus et al. 2016) and soilmanagement (e.g., Ladefoged et al. 2005) in the Mediterranean and Pacific, as well as fishpond aquaculture in Hawai'i.

Clearly, investment in landscape capital is not an islandspecific phenomenon. Nonetheless, in the face of substantial change in biophysical systems deriving from colonization impacts, we might expect such investment in island contexts to be: (a) comparatively more spatially expansive than in nonisland contexts, because of biophysical disruption affecting more of the total productive landscape; (b) more costly per capita, because of a relatively low population/high investment cost ratio; and (c) more central to maintaining surplus flows, because capital-intensive systems such as terracing or aquaculture should constitute a greater proportion of the total subsistence system.

Essentially, to mitigate risk, non-hierarchical societies with limited inter-generational transmission of wealth would have initially invested heavily in spatially heterogeneous programs of landscape modification. This would have significantly transformed how quickly and in which parts of the community surplus accumulated, with spatially variable landscape investment driving spatially (and thereby socially) variable patterns of productivity and thereby allowing capital to aggregate rapidly and unevenly. Differential investment of labor and resources in mitigatory infrastructure may be more significant in the context of insular social organization often counterintuitively exhibiting evidence for hierarchical and complex social forms. This runs against the grain of prevailing social evolutionary theory and its emphasis on demographic blocs and large surpluses.

Clearly, linking landscape capital and emergent systems of inequitable wealth distribution is not an original argument; however, this should be contextualized within our understanding of insular carrying capacity and recent discussions of the precise socioeconomic mechanisms that can drive exaggeratedly skewed wealth-distributions. Piketty (2014), exploring conditions that may promote or depress wealth inequality, demonstrates that very skewed wealth-distributions may emerge in contexts of comparatively high returns on capital and comparatively depressed overall growth. This has a central, hitherto under-appreciated relevance as a mechanism for explaining emergent inequality in low productivity environments. Island contexts - relatively marginal compared to, for example, extensive continental patches of fluvial or loessial Quaternary sediments - should permit relatively low overall socioeconomic growth under conditions of Neolithic subsistence strategies. Investment of landscape capital by those segments of society with the capacity to do so should drive exaggeratedly high returns relative to comparable non-insular (i.e., a more productive and resilient) contexts. This approximates a low growth-high capital returns scenario, driving greater disparities in wealth than in more productive or less 
biophysically responsive environments. This is beyond the scope of this paper, but addressing the extent to which finite and predictable responses to general ecodynamic processes drive similarly comparable emergent effects in terms of social organization and wealth disparity is an important focus for future research.

\section{Conclusions}

Islands, despite their evident diversity in terms of physiography and biology, share certain ecological tendencies in terms of responsiveness to invasion. Neolithic packages, also evidently enormously diverse, nonetheless are organized such that their introduction tends to radically destabilize island biota. A range of data proxies indicate that this destabilization manifested along several predictable pathways during the Neolithic colonization of Mediterranean, Pacific, and Caribbean islands. The predictable and recognizable effects of biological invasions should, I suggest, be evident also in those physical systems that interface with biota, which experience predictable types of process as they converge via a general ecodynamic trajectory. This process of environmental convergence has significant implications for insular human ecology, not least in terms of providing routes into testing spatio-temporal models of maritime dispersal and highlighting the deep history of human impacts on the geosphere, rather than simply on the biosphere.

Beyond the implications more usually considered within the framework of human or historical ecology, this model has ramifications for social organization itself that I have addressed here only briefly. Environmental convergence would have demanded mitigation strategies on the part of island colonists, in particular comparatively expansive (for small-scale Neolithic societies) programs of capital investment. Island environments nonetheless remain comparatively marginal, and it is in the dynamic tension between capital investment, growth, and returns (different ratios of which can drive or suppress emergent inequalities), Neolithic egalitarian ideologies, and marginal and less resilient environments (islands are exemplary, but perhaps not unique in their biophysical responsiveness) that future work may locate the kernel of emergent insular social complexity.

Finally, I stress that islands are not essentially representative of qualitatively distinct or otherwise unique types of environmental organization. Instead, they are illustrative of broader processes by virtue of the extent to which they are exemplary of the tendency of the surface of the geosphere to be both heterogeneous and scalar in this heterogeneity. In this sense, then, the issue becomes one of relative scale (cf. Brose et al. 2004), and we might suppose that the types of socioecological constraint sketched above are noteworthy in insular perspective only to the degree that they are felt more acutely and rapidly in more restricted 'island' contexts than others. Recognizing that these dynamics anticipate largerscale and longer-term continental processes would contribute substantially to bridging the divide between palaeoenvironmental and ecodynamic research on the one hand, and models of social evolutionary development on the other.

Acknowledgments I would like to thank Scott Fitzpatrick, Christina Giovas, John Cherry, and Elizabeth Murphy for their respective considered and perspicacious critiques of an earlier version of this paper; Christina in particular provided detailed and extremely thoughtful feedback. This paper grew from joint work with Todd Braje, Scott Fitzpatrick, and Jon Erlandson, ultimately published in Environmental Conservation, and I thank them for both their invitation to collaborate and their collegiality; it draws draws on a continuing collaboration with John Cherry, addressing the emergence of complex societies in the Mediterranean. This research was undertaken while holding a Renfrew Fellowship in the McDonald Institute for Archaeological Research and Homerton College, University of Cambridge, for which support I am grateful.

Compliance with Ethical Standards The research presented in this paper did not involve Human Participants and/or Animals.

Conflict of Interest The author declares that he has no conflict of interest.

Open Access This article is distributed under the terms of the Creative Commons Attribution 4.0 International License (http:// creativecommons.org/licenses/by/4.0/), which permits unrestricted use, distribution, and reproduction in any medium, provided you give appropriate credit to the original author(s) and the source, provide a link to the Creative Commons license, and indicate if changes were made.

\section{References}

Airoldi L., and Cinelli F. (1997). Effects of sedimentation on subtidal macroalgal assemblages: An experimental study from a mediterranean rocky shore. Journal of Experimental Marine Biology and Ecology 215(2): 269-288.

Alcover J. A., Sans A., and Palmer M. (1998). The extent of extinctions of mammals on islands. Journal of Biogeography 25(5): 913-918.

Allen M. S. (2015). Dietary opportunities and constraints on islands: A multi-proxy approach to diet in the southern Cook Islands. In LeeThorp J., and Katzenberg M. A. (eds.), The Oxford Handbook of the Archaeology of Diet, Oxford University Press, Oxford. https://doi. org/10.1093/oxfordhb/9780199694013.013.2.

Anderson S. P. (2012). How deep and steady is earth's surface? Geology 40(9): 863-864.

Angel A., Wanless R. M., and Cooper J. (2009). Review of impacts of the introduced house mouse on Islands in the Southern Ocean: are mice equivalent to rats? Biological Invasions 11: 1743-1754.

Arranz-Otaeguia A., Colledge S., Zapata L., Teira-Mayolini L. C., et al (2016). Regional diversity on the timing for the initial appearance of cereal cultivation and domestication in Southwest Asia. Proceedings of the National Academy of Sciences 113(49): 14001-14006.

Athens J. S. (2009). Rattus exulans and the catastrophic disappearance of Hawai'i's native lowland forest. Biological Invasions 11: 1489-1501.

Baiser B., and Lockwood J. L. (2011). The relationship between functional and taxonomic homogenization. Global Ecology and Biogeography 20: 134-144.

Barker G., and Richards M. B. (2013). Foraging-farming transitions in Island Southeast Asia. Journal of Archaeological Method and Theory 20(2): 256-280. 
Barnosky A. D., Matzke N., Tomiya S., Wogan G. O. U., et al (2011). Has the earth's sixth mass extinction already arrived? Nature 471: 51-57.

Bartlett L. J., Williams D. R., Prescott G. W., Balmford A., et al (2015). Robustness despite uncertainty: regional climate data reveal the dominant role of humans in explaining global extinction of late quaternary megafauna. Ecography 39(2): 152-161.

Bautista S., Mayor Á. G., Bourakhouadar J., and Bellot J. (2007). Plant spatial pattern predicts hillslope runoff and erosion in a semiarid mediterranean landscape. Ecosystems 10: 987-998.

Bellwood P. (2011). Holocene population history in the pacific region as a model for worldwide food producer dispersals. Current Anthropology 52(Supplement 4): S363-S378.

Berendse F., van Ruijven J., Jongejans E., and Keesstra S. (2015). Loss of plant species diversity reduces soil erosion resistence. Ecosystems 18: 881-888.

Bergmann J., Verbruggen E., Heinze J., Xiang D., et al (2016). The interplay between soil structure, roots, and microbiota as a determinant of plant-soil feedback. Ecology and Evolution 6: 7633-7644.

Bevan A., and Conolly J. (2011). Terraced fields and mediterranean landscape structure: an analytical case study from Antikythera, Greece. Ecological Modelling 222(7): 1303-1314.

Boivin N. L., Zeder M. A., Fuller D. Q., Crowther A., et al (2016). Ecological consequences of human niche construction: examining long-term anthropogenic shaping of global species distributions. Proceedings of the National Academy of Sciences 113: 6388-6396.

Bolton M., Stanbury A., Baylis A. M. M., and Cuthbert R. (2014). Impact of introduced house mice (Mus musculus) on burrowing seabirds on Steeple Jason and Grand Jason Islands, Falklands, South Atlantic. Polar Biology 37: 1659-1668.

Borregaard M. K., Amorim I. R., Borges P. A. V., Cabral J. S., et al (2016). Oceanic island biogeography through the lens of the general dynamic model: Assessment and prospect. Biological Reviews. https://doi.org/10.1111/brv.12256.

Bover P., Valenzuela A., Torres E., Cooper A., et al (2016). Closing the gap: New data on the last documented Myotragus and the first human evidence on Mallorca (Balearic Islands, Western Mediterranean Sea). The Holocene 26(11): 1887-1891.

Boyer A. G. (2010). Consistent ecological selectivity through time in Pacific island avian extinctions. Conservation Biology 24(2): 511519.

Boyer A. G., and Jetz W. (2014). Extinctions and the loss of ecological function in island bird communities. Global Ecology and Biogeography 23: 679-688.

Braje T. D., and Erlandson J. (2013). Human acceleration of animal and plant extinctions: A late Pleistocene, Holocene, and Anthropocene continuum. Anthropocene 4: 14-23.

Braje T. D., Leppard T. P., Fitzpatrick S. M., and Erlandson J. M. (2017a). Archaeology, historical ecology and anthropogenic island ecosystems. Environmental Conservation. https://doi.org/10.1017/ S0376892917000261.

Braje T. D., Rick T. C., Szpak P., Newsome S. D., et al (2017b). Historical ecology and the conservation of large, hermaphroditic fishes in Pacific coast kelp forest ecosystems. Science Advances 3: e1601759.

Brose U., Ostling A., Harrison K., and Martinez N. D. (2004). Unified spatial scaling of species and their trophic interactions. Nature 428: 167-171.

Brumm A., Jensen G. M., van den Bergh G. D., Morwood M. J., et al (2010). Hominins on Flores, Indonesia, by one million years ago. Nature 464: 748-752.

Burney D. A., and Flannery T. F. (2005). Fifty millennia of catastrophic extinctions after human contact. Trends in Ecology \& Evolution 20(7): 395-401.

Callaway R. M., Thelen G. C., Rodriguez A., and Holben W. E. (2004). Soil biota and exotic plant invasion. Nature 427: 731-733.
Campbell D. J., and Rudge M. R. (1984). Vegetation changes induced over ten years by goats and pigs at port Ross, Auckland Islands (subantarctic). New Zealand Journal of Ecology 7: 103-118.

Cassey P., Lockwood J. L., Blackburn T. M., and Olden J. D. (2007). Spatial scale and evolutionary history determine the degree of taxonomic homogenization across island bird assemblages. Diversity and Distributions 13: 458-466.

Ceballos G., Ehrlich P. R., Barnosky A. D., García A., et al (2015). Accelerated modern human-induced species losses: Entering the sixth mass extinction. Science Advances 1(5). https://doi.org/10. 1126/sciadv. 1400253

Chapuis J.-L., Barnaud G., and Boussès P. (1994). Alien mammals, impact and management in the French subantarctic islands. Biological Conservation 67: 97-104.

Chynoweth M. W., Litton C. M., Lepczyk C. A., Hess S. C., et al (2013). Biology and impacts of Pacific island invasive species. 9. Capra hircus, the feral goat (Mammalia: Boivdae). Pacific Science 67: 141-156.

Çilingiroĝlu Ç. (2005). The concept of "Neolithic package": Considering its meaning and applicability. Documenta Praehistorica 32: 1-13.

Cole R. J., Litton C. M., Koontz M. J., and Loh R. K. (2012). Vegetation recovery 16 years after feral pig removal from a wet Hawaiian forest. Biotropica 44(4): 463-471.

Cooper A., Turney C., Hughen K. A., Brook B. W., et al (2015). Abrupt warming events drove late Pleistocene Holarctic megafaunal turnover. Science 349: 602-606.

Cronk Q. C. B. (1989). The past and present vegetation of St Helena. Journal of Biogeography 16: 47-64.

Crowther A., Lucas L., Helm R., Horton M., Shipton C., et al (2016). Ancient crops provide first archaeological signature of the westward Austronesian expansion. Proceedings of the National Academy of Sciences 113(24): 6635-6640.

Cucchi T., Vigne J.-D., and Auffray J.-C. (2005). First occurrence of the house mouse (Mus musculus domesticus Schwarz \& Schwarz, 1943) in the western Mediterranean: A zooarchaeological revision of subfossil occurrences. Biological Journal of the Linnaean Society 84: 429-445.

Denham T. (2011). Early agriculture and plant domestication in new Guinea and island Southeast Asia. Current Anthropology 52(supplement 4): S379-S395.

Di Stefano C., Ferro V., Pampalone V., and Sanzone F. (2013). Field investigation of rill and ephemeral gully erosion in the Sparacia experimental area, South Italy. Catena 101: 226-234.

Downey P. O., and Richardson D. M. (2016). Alien plant invasions and native plant extinctions: A six-threshold framework. AoB Plants. https://doi.org/10.1093/aobpla/plw047.

Dunkell D. O., Bruland G. L., Evenson C. I., and Litton C. M. (2011). Runoff, sediment transport, and effects of feral pig (Sus scrofa) exclusion in a forested Hawaiian watershed. Pacific Science 65(2): 175-194.

Ehrenfeld J. G., Ravit B., and Elgersma K. (2005). Feedback in the plantsoil system. Annual Review of Environment and Resources 30: 75 115.

Fabricius K. E. (2005). Effects of terrestrial runoff on the ecology of corals and coral reefs: Review and synthesis. Marine Pollution Bulletin 50(2): 125-146.

Fang H., Sung L., and Tang Z. (2014). Effects of rainfall and slope on runoff, soil erosion and rill development: An experimental study using two loess soils. Hydrological Processes 29(11): 2649-2658.

Fitzpatrick S. M. (2015). The pre-Columbian Caribbean: Colonization, population dispersal, and island adaptations. PaleoAmerica 1(4): 305-331.

Fordham D. A., and Brook B. W. (2010). Why tropical island endemics are acutely susceptible to global change. Biodiversity and Conservation 19: 329-342. 
Fuller D. Q., Boivin N., Hoogervorst T., and Allaby R. (2011). Across the Indian Ocean: The prehistoric movement of plants and animals. Antiquity 85: 544-558.

Garcia-Fayos P., and Bochet E. (2009). Indication of antagonistic interaction between climate change and erosion on plant species richness and soil properties in semiarid Mediterranean ecosystems. Global Change Biology 15: 306-318.

Gilbert B., and Levine J. M. (2013). Plant invasions and extinction debts. Proceedings of the National Academy of Sciences 110(5): 1744 1749.

Giovas C. M., LeFebvre M. J., and Fitzpatrick S. M. (2011). New records for prehistoric introduction of Neotropical mammals to the West Indies: Evidence from Carriacou, lesser Antilles. Journal of Biogeography 39(3): 476-487.

Giovas C. M., Kamenov G. D., Fitzpatrick S. M., and Krigbaum J. (2016). $\mathrm{Sr}$ and $\mathrm{Pb}$ isotopic investigation of mammal introductions: Pre-Columbian zoogeographic records from the lesser Antilles, West Indies. Journal of Archaeological Science 69: 39-53.

Gunn B. F., Baudouin L., and Olsen K. M. (2011). Independent origins of cultivated coconut (Cocos nucifera $\mathrm{L}$.) in the old world tropics. PloS One 6(6). https://doi.org/10.1371/journal.pone.0021143.

Gyssels G., Poesen J., Bochet E., and Li Y. (2005). Impact of plant roots on the resistance of soils to erosion by water: A review. Progress in Physical Geography 29: 189-217.

Hanna E., and Cardillo M. (2014). Island mammal extinctions are determined by interactive effects of life history, island biogeography and mesopredator suppression. Global Ecology and Biogeography 23: 395-404.

Hata K., Kohri M., Morita S., Hiradate S., et al (2014). Complex interrelationships among above ground biomass, soil chemical properties, and events caused by feral goats and their eradication in a grassland ecosystem of an island. Ecosystems 17: 1082-1094.

Helmus M. R., Mahler L. D., and Losos J. B. (2014). Island biogeography of the Anthropocene. Nature 513: 543-546.

Hocknull S. A., Piper P. J., van den Bergh G. D., Due R. A., et al (2009). Dragon's paradise lost: Palaeobiogeography, evolution and extinction of the largest-ever terrestrial lizards (Varanidae). PloS One 4(9). https://doi.org/10.1371/journal.pone.0007241.

Hunt T. L. (2007). Rethinking Easter Island's ecological catastrophe. Journal of Archaeological Science 34: 485-502.

Kirch P. V. (1984). The evolution of the Polynesian chiefdoms, Cambridge University Press, Cambridge.

Kirch P. V. (1996). Late Holocene human-induced modifications to a central Polynesian island ecosystem. Proceedings of the National Academy of Sciences 93: 5296-5300.

Kirch P. V., Christensen C. C., and Steadman D. W. (2009). Subfossil land snails from Easter Island, including Hotumatua anakenana, new genus and species (Pulmonata: Achatinellidae). Pacific Science 63(1): 105-122.

Kirkels F. M. S. A., Cammeraat L. H., and Kuhn N. J. (2014). The fate of soil organic carbon upon erosion, transport and deposition in agricultural landscapes - A review of different concepts. Geomorphology 226: 94-105.

Kueffer C., Daehler C. C., Torres-Santana C. W., Lavergne C., et al (2010). A global comparison of plant invasions on oceanic islands. Perspectives in Plant Ecology, Evolution and Systematics 12(2): 145-161.

Ladefoged T. N., Stevenson C. M., Vitousek P. M., and Chadwick O. A. (2005). Soil nutrient depletion and the collapse of Rapa Nui society. Rapa Nui Journal 19: 100-105.

Lande R. (1993). Risks of population extinction from demographic and environmental stochasticity and random catastrophes. The American Naturalist 142(6): 911-927.

Larson G., Liu R., Zhao X., Yuan J., et al (2010). Patterns of east Asian pig domestication, migration, and turnover revealed by modern and ancient DNA. Proceedings of the National Academy of Sciences 107(17): 7686-7691.

Loehle C., and Eschenbach W. (2012). Historical bird and terrestrial mammal extinction rates and causes. Diversity and Distributions 18: 84-91.

Losos J. B. (2011). Covergence, adaptation, and constraint. Evolution 65: $1827-1840$.

Louys J., Curnoe D., and Tong H. (2007). Characteristics of Pleistocene megafauna extinctions in Southeast Asia. Palaeogeography, Palaeoclimatology, Palaeoecology 243(1-2): 152-173.

MacArthur R. H., and Wilson E. O. (1967). The theory of island biogeography, Princeton University Press, Princeton.

Maher K., and Chamberlain C. P. (2014). Hydrologic regulation of chemical weathering and the geological carbon cycle. Science 343: 1502 1504.

Marschner H., and Marschner P. (2012). Mineral nutrition of higher plants, 3rd edn., Elsevier/Academic Press, Amsterdam.

Matisoo-Smith L., Roberts R. M., Irwin G. J., Allen J. S., et al (1998). Patterns of prehistoric human mobility in Polynesia indicated by mtDNA from the Pacific rat. Proceedings of the National Academy of Sciences 95: 15145-15150.

McGhee G. (2011). Convergent evolution: Limited forms most beautiful, MIT Press, Cambridge.

McKinney M. L., and Lockwood J. L. (1999). Biotic homogenization: A few winners replacing many losers in the next mass extinction. Trends in Ecology \& Evolution 14: 450-453.

McWethy D. B., Whitlock C., Wilmshurst J. M., McGlone, et al (2010). Rapid landscape transformation in South Island, New Zealand, following initial Polynesian settlement. Proceedings of the National Academy of Sciences 107(50): 21343-21348.

Mickleburgh H., and Pagan-Jimenez J. R. (2012). New insights into the consumption of maize and other food plants in the pre-Columbian Caribbean from starch grains trapped in human dental calculus. Journal of Archaeological Science 39(7): 2468-2478.

Mulder C. P. H., Jones H. P., Kameda K., Palmborg C., et al (2011). Impacts of seabirds on plant and soil properties. In Mulder C. P. H., Anderson W. B., Towns D. R., and Bellingham P. J. (eds.), Seabird Islands: Ecology, Invasion, and Restoration, Oxford University Press, New York, pp. 135-176.

Murphy M. J., Inman-Narahari F., Ostertag R., and Litton C. M. (2014). Invasive feral pigs impact native tree ferns and woody seedlings in Hawaiian forest. Biological Invasions 16: 63-71.

Mwendera E. J., Mohammed Saleem M. A., and Dibabe A. (1997). The effect of livestock grazing on surface runoff and soil erosion from sloping pasture lands in the Ethiopian highlands. Australian Journal of Experimental Agriculture 37: 421-430.

Nadeu E., Van Oost K., Boix-Fayos C., and de Vente J. (2014). Importance of land use patterns for erosion-induced carbon fluxes in a Mediterranean catchment. Agriculture, Ecosystems and Environment 189: 181-189.

Nogales M., Martín A., Tershy B. R., Donlan C. J., et al (2004). A review of feral cat eradication on islands. Conservation Biology 18(2): 310 319.

Nogueira-Filho S. L. G., Nogueira S. S. C., and Fragoso J. M. V. (2009). Ecological impacts of feral pigs in the Hawaiian islands. Biodiversity and Conservation 18: 3677-3683.

Nunn N., and Qian N. (2010). The Columbian exchange: A history of disease, food, and ideas. Journal of Economic Perspectives 24: 163 188.

O'Dowd D. J., Green P. T., and Lake P. S. (2003). Invasional 'meltdown' on an oceanic island. Ecology Letters 6: 812-817.

Olden J. D. (2006). Biotic homogenization: A new research agenda for conservation biogeography. Journal of Biogeography 33: 2027 2039. 
Olden J. D., and Poff N. L. (2003). Toward a mechanistic understanding and prediction of biotic homogenization. American Naturalist 162: 442-460.

Olden J. D., Poff N. L., Douglas M. R., Douglas M. E., et al (2004). Ecological and evolutionary consequences of biotic homogenization. Trends in Ecology \& Evolution 19: 18-24.

Pagán-Jiménez J. R., Rodríguez-Ramos R., Reid B. A., van den Bel M., et al (2015). Early dispersals of maize and other food plants into the Southern Caribbean and Northeastern South America. Quaternary Science Reviews 123(1): 231-246.

Perkins L. B., Hatfield G., and Espeland E. K. (2016). Invasive grasses consistently create similar plant-soil feedback types in soils collected from geographically distant locations. Journal of Plant Ecology 9(2): 180-186.

Perron J. P., Richardson P. W., Ferrier K. L., and Lapôtre M. (2012). The root of branching river networks. Nature 492: 100-103.

Piketty T. (2014). Capital in the Twenty-First Century, Harvard University Press, Cambridge.

Pimentel D. (2006). Soil erosion: A food and environmental threat. Environment, Development and Sustainability 8: 119-137.

Pimentel D., and Kounang N. (1998). Ecology of soil erosion in ecosystems. Ecosystems 1: 416-426.

Pitt J., Gillingham P. K., Maltby M., and Stewart J. R. (2016). New perspectives on the ecology of early domestic fowl: An interdisciplinary approach. Journal of Archaeological Science 74: 1-10.

Quinton J. N., Govers G., Van Oost K., and Bardgett R. D. (2010). The impact of agricultural soil erosion on biogeochemical cycling. Nature Geoscience 3: 311-314.

Quintus S., Allen M. S., and Ladefoged T. N. (2016). In surplus and in scarcity: Agricultural development, risk management, and political economy, Ofu Island, American Samoa. American Antiquity 81: 273-293.

Ratcliffe F. N., and Calaby J. H. (1958). Rabbit. In Chisholm A. H. (ed.), The Australian Encyclopedia vol Vol. 7, Angus and Robertson Ltd., Sydney, pp. 340-347.

Rick T. C., Hofman C. A., Braje T. J., Maldonado J. E., et al (2012). Flightless ducks, giant mice and pygmy mammoths: Late quaternary extinctions on California's Channel Islands. World Archaeology 44(1): $3-20$.

Ritchie J. C., McCarthy G. W., Venteris E. R., and Kaspar T. C. (2007). Soil and soil organic carbon redistribution on the landscape. Geomorophology 89: 163-171.

Rosenblad K. C., and Sax D. (2016). A new framework for investigating biotic homogenization and exploring future trajectories: Oceanic island plant and bird assemblages as a case study. Ecography 39 . https://doi.org/10.1111/ecog.02652.

Rybicki J., and Hanski I. (2013). Species-area relationships and extinctions caused by habitat loss and fragmentation. Ecology Letters 16: $27-38$.

Sánchez-Piñero F., and Polis G. A. (2000). Bottom-up dynamics of allochthonous input: Direct and indirect effects of seabirds on islands. Ecology 81(11): 3117-3132.

Schittko C., Runge C., Strupp M., Wolff S., et al (2016). No evidence that plant-soil feedback effects of native and invasive plant species under glasshouse conditions are reflected in the field. Journal of Ecology 104: $1243-1249$.

Sekercioglu C. H. (2011). Functional extinctions of bird pollinators cause plant declines. Science 331: 1019-1020.

Shaw J. D., Spear D., Greve M., Chown S. L., et al (2010). Taxonomic homogenization and differentiation across Southern Ocean islands differ among insects and vascular plants. Journal of Biogeography 37(2): 271-228.

Simberloff D. (2009). Rats are not the only introduced rodents producing ecosystem impacts on islands. Biological Invasions 11: 1735-1742.

Stahl P. W. (2009). Adventive vertebrates and historical ecology in the pre-Columbian Neotropics. Diversity 1(2): 151-165.
Steadman D. W., and Franklin J. (2015). Changes in a west Indian bird community since the late Pleistocene. Journal of Biogeography 42: 426-438.

Steadman D. W., and Martin P. S. (2003). The late quaternary extinction and future resurrection of birds on Pacific island. Earth-Science Reviews 61: 133-147.

Steadman D. W., White J. P., and Allen J. (1999). Prehistoric birds from New Ireland, Papua New Guinea: Extinctions on a large Melanesian island. Proceedings of the National Academy of Sciences 96: 2563 2568.

Steadman D. W., Martin P. S., MacPhee R. D. E., Jull A. J. T., et al (2005). Asynchronous extinction of late quaternary sloths on continents and islands. Proceedings of the National Academy of Sciences 102: 11763-11768.

Stern D. L. (2013). The genetic causes of convergent evolution. Nature Reviews Genetics 14: 751-764.

Stinson K. A., Campbell S. A., Powell J. R., Wolfe B. E., et al (2006). Invasive plant suppresses the growth of native tree seedlings by disrupting belowground mutualisms. PLoS Biology. https://doi. org/10.1371/journal.pbio.0040140.

Storlazzi C. D., Norris B. K., and Rosenberger K. J. (2015). The influence of grain size, grain color, and suspended-sediment concentration on light attenuation: Why fine-grained terrestrial sediment is bad for coral reef ecosystems. Coral Reefs 34(3): 967-975.

Stuart A. J. (2015). Late quaternary megafaunal extinctions on the continents: A short review. Geological Journal 50(3): 338-363.

Suding K. N., Harpole W. S., Fukami T., Kulmatiski A., et al (2013). Consequences of plantsoil feedbacks in invasion. Journal of Ecology 101: 298-308.

Szabo J. K., Khwaja N., Garnett S. T., and Butchart S. H. M. (2012). Global patterns and drivers of avian extinctions at the species and subspecies level. PloS One 7(10). https://doi.org/10.1371/journal. pone. 0047080 .

Tebbett S. B., Goatley C. H. R., and Bellwood D. R. (2017). Fine sediments suppress detritivory on coral reefs. Marine Polution Bulletin 114(2): 934-940.

Traveset A., and Richardson D. M. (2006). Biological invasions as disruptors of plant reproductive mutualisms. Trends in Ecology \& Evolution 21: 208-216.

van den Bergh G. D., Meijer H. J. M., Awe R. D., Morwood M. J., et al (2009). The Liang Bua faunal remains: A 95 k.Yr. sequence from Flores, East Indonesia. Journal of Human Evolution 57(5): 527 537.

Vereecken H., Schnepf A., Hopmans J. W., Javaux M., et al (2016). Modeling soil processes: Review, key challenges, and new perspectives. Vadose Zone Journal 15(5). https://doi.org/10.2136/vzj2015. 09.0131.

Vigne J.-D. (1988). Biogéographie insulaire et anthropologie des sociétés néolithiques méditerranéennes: hérisson, renard et micromammifères. Anthropozoologica 8: 31-52.

Villavicencio N. A., Lindsey E. L., Martin F. M., Borrero L. A., et al (2015). Combination of humans, climate, and vegetation change triggered late quaternary megafauna extinction in the Última Esperanza region, southern Patagonia, Chile. Ecography 39(2): 125-140.

Wanless R. M., Angel A., Cuthbert R. J., Hilton G. M., et al (2007). Can predation by invasive mice drive seabird extinctions? Biology Letters 3: 241-244.

Weigelt P., Jetz W., and Kreft H. (2013). Bioclimatic and physical characterization of the world's islands. Proceedings of the National Academy of Sciences 110(38): 15307-15312.

Whittaker R. J., Ladle R. J., Araújo M. B., Fernández-Palacios J. M., et al (2007). The island immaturity - Speciation pulse model of island evolution: An alternative to the "diversity begets diversity" model. Ecography 30: 321-327. 
Whittaker R. J., Triantis K. A., and Ladle R. J. (2008). A general dynamic theory of oceanic island biogeography. Journal of Biogeography 35 : 977-994.

Wilcove D. S., Rothstein D., Dubow J., Philips A., et al (1998). Quantifying threats to imperiled species in the United States. Bioscience 48: 607-615.

Willcox G. (2013). The roots of cultivation in southwestern Asia. Science 341: 39-40.

Willett S. D., McCoy S. W., Perron J. T., Goren L., et al (2014). Dynamic reorganization of river basins. Science 343. https://doi.org/10.1126/ science. 1248765 .

Wolfe B. E., and Klironomos J. N. (2005). Breaking new ground: Soil communities and exotic plant invasion. Bioscience 55(6): 477-487.
Wood P. J., and Armitage P. D. (1997). Biological effects of fine sediment in the lotic environment. Environmental Management 21(2): 203 217.

Woodward D. E. (1999). Method to predict cropland ephemeral gully erosion. Catena 37: 393-399.

Yocom C. F. (1967). Ecology of feral goats in Haleakala National Park, Mauii, Hawaii. The American Midland Naturalist 77: 418-451.

Yong-Zhong S., Yu-Lin L., Jian-Yuan C., and Wen-Zhi Z. (2005). Influences of continuous grazing and livestock exclusion on soil properties in a degraded sandy grassland, Inner Mongolia, northern China. Catena 59: 267-278.

Zeder M. A. (2008). Domestication and early agriculture in the Mediterranean basin: Origins, diffusion, and impact. Proceedings of the National Academy of Sciences 105(33): 11597-11604. 